\title{
Effect of the ACE inhibitor enalapril on plasma ACE concentration in horses with left side heart valve insufficiency
}

\author{
Heidrun Gehlen and Maike Rapp \\ Klinik für Pferde, Allgemeine Chirurgie und Radiologie des Fachbereiches Veterinärmedizin der Freien Universität Berlin
}

\begin{abstract}
Summary: Even though angiotensin-converting enzyme (ACE) inhibitors are often used in horses, only a few studies exist that investigate the effect of these drugs in horses suffering from heart disease. The aim of this work was to examine the effect of the ACE inhibitor enalapril on the plasma ACE concentration of horses diagnosed with a left-sided heart valve insufficiency. We hypothesize that the use of the ACE inhibitor enalapril leads to a lowered ACE concentration in the equine blood plasma of horses suffering from a left-side heart valve insufficiency. Therefor we evaluated twenty-five horses with aortic and/or mitral valve insufficiency. All animals received daily dose of enalapril per os $(0.5 \mathrm{mg} /$ $\mathrm{kg}$ ) over a period of three months. The horses were divided into two groups. Horses in Group 1 were examined immediately prior to the trials and after the three-month therapy period. Horses in Group 2 were examined a third time, three months prior to the start of treatment with enalapril. Serum ACE concentration was measured photometrically. No horse showed any signs of noticeable adverse effects. A statistically significant increase in ACE activity has been recorded in Group 1 and Group 2 under the therapy with enalapril $(p=0.00)$. While no treatment was performed on the horses in Group 2, no statistically significant difference in ACE activity could be shown $(p=0.00)$. The study showed an effect of the ACE inhibitor enalapril on the renin-angiotensin-aldosterone system in horses diagnosed with left-side heart valve insufficiency. However, our results contradicted expectations that enalapril would lead to a lowered ACE concentration in the equine blood plasma. Further studies on cardiac efficacy would be desirable.
\end{abstract}

Keywords: ACE inhibitor, serum ACE activity, horses, heart valve insufficiency

Citation: Gehlen H., Rapp M. (2020) Effect of the ACE inhibitor enalapril on plasma ACE concentration in horses with left side heart valve insufficiency. Pferdeheilkunde 36, 137-142; DOI 10.21836/PEM20200206

Correspondence: Prof. Dr. Heidrun Gehlen, Klinik für Pferde, Allgemeine Chirurgie und Radiologie des Fachbereiches Veterinärmedizin der Freien Universität Berlin; heidrun.gehlen@fu-berlin.de

Submitted: November 12, 2019 | Accepted: January 27, 2020

\section{Introduction}

Activation of the renin-angiotensin-aldosterone system (RAAS) plays an essential role during heart diseases (Swedeberg et al. 1990, Packer 1992, Kasi et al. 2007, Richter et al. 2014). Angiotensin-converting-enzyme (ACE) inhibitors may provide a therapeutic starting point to counteract RAAS activation (Richter et al. 2014). Two main effects of ACE inhibitors are the inhibition of angiotensin II production and the inhibition of the degradation of bradykinin (Unger 2002, Fleming 2006). A decreased angiotensin II concentration causes venous and arterial vasodilation and reduced plasma volume. A reduced plasma volume leads to a lowered pre- and afterload without increasing heart rate. It results in an increased ejection fraction and reduced diastolic volume (Richter et al. 2014). Accumulation of bradykinin under ACE inhibitor therapy can stimulate the production of nitric oxides and prostacyclins (Johnston et al. 1997). Another mode of action is created by the accumulation of $\mathrm{N}$-acetyl-seryl-aspartyl-lysyl-proline, an ACE substrate. This substrate prevents deposition of collagen fibers in the damaged heart muscle and activation of the RAAS (Fleming 2006). Use of ACE inhibitors in humans is widespread and effects were studied with various large-scale trials (Endringer et al. 2014, Fagyas et al., 2014, Schilders et al. 2014). The ACE inhibitors are considered to be car- dioprotective in horses with mitral and aortic valve insufficiency and are used therapeutically in heart failure (Bonagura et al. 2010, Gehlen and Ammer 2010, Sage and Mogg 2010). There are only a few existing studies on the use of ACE inhibitors in horses with heart diseases and the exact dosage and its precise effect are still largely unknown (Guglielmini et al. 2002, Gehlen et al. 2003, Goltz et al. 2009, Bonagura et al. 2010). Enalapril is one of the recommended ACE inhibitors, although previously published studies reported a poor oral bioavailability in healthy horses (Gardner et al. 2004, Gomez-Diez et al. 2014).

The aim of this work was to examine the effect of Enalapril (Enalatab ${ }^{\circledR} 20 \mathrm{mg}$, CP-Pharma Handelsgesellschaft mbH, Burgdorf, Germany) per os on the ACE concentration in equine plasma blood samples.

\section{Materials and Methods}

Twenty-five horses ultrasonically diagnosed with a mitral and/ or aortic valve insufficiency were included. Cardiac ultrasonographic examination was performed on all horses based on a cardiac murmur, which was discovered randomly during routine examinations. 
The breeds represented included 18 warmbloods, three standardbreds, two Anglo-Arabians, one thoroughbred and one American quarter horse. The mean age was $16.4( \pm 8.0)$ years. The average body weight was $536( \pm 76) \mathrm{kg}$ and the average size $165( \pm 10) \mathrm{cm}$.

The 25 horses were divided into two groups. Horses in Group $1(n=11)$ were examined twice in a three-month interval. None of the animals received any medication prior to the first examination. The animals in Group 1 were treated with enalaprilmaleat (Enalatab ${ }^{\circledR} 20$ mg, CP-Pharma Handelsgesellschaft mbH, Burgdorf, Germany) once a day per os at dose $0.5 \mathrm{mg} / \mathrm{kg}$ in between the first and the second examination. Six of these patients were diagnosed with an aortic and five with a mitral valve insufficiency.

Patients in Group $2(n=14)$ were examined three times at intervals of three months each (examination period total six months). The horses received no therapeutic medication in the first three months. In the following three months, the animals were administered enalaprilmaleat once a day, equivalent to the horses in Group 1. Six patients showed an aortic and eight a mitral valve insufficiency in Group 2.

All patients were hospitalized overnight for the examination trials. Each examination included a clinical general examination, a further clinical examination of the cardiovascular system and blood sampling for determination of the ACE activity. In addition, an analysis of electrolytes and clinical chemistry was performed on the blood samples. Blood samples were taken at 7.45 a.m. when horses were already fed and rested in their stable. Electrolytes and clinical chemistry were routinely measured from a EDTA or heparin-stabilized samples in the clinic's own laboratory (PoCH-100, scil animal care company GmbH, Viernheim, Germany and Cobas b 123, Roche Diagnostics $\mathrm{GmbH}$, Mannheim, Germany).

Refrigerated 2-ml heparin tubes (Lithium-Heparin-Monovetten, Sarstedt AG \& Co., Nümbrecht, Germany) were used to determine the ACE activity. The samples were centrifuged (Z326K, Hermle Labortechnik GmbH, Wehingen, Germany) at $2000 \mathrm{rpm}$ for $10 \mathrm{~min}$ at $4{ }^{\circ} \mathrm{C}$, immediately after collection. The resulting plasma was pipetted into previously labelled cryo tubes (Simport $1.5 \mathrm{ml}$, Micrewtube, Bernard-Pilon, Canada) and stored refrigerated at $80^{\circ} \mathrm{C}$ until further analysis (Skadi ${ }^{\circledR}$ Green Line, Ede, Netherlands).

The samples were transported on dry ice to the laboratory (Laboklin $\mathrm{GmbH} \&$ Co. KG, Bad Kissingen, Germany) for subsequent analysis. Each sample was measured twice and the mean value was calculated. Analysis was carried out by photometrical determination of enzyme activity in the blood serum using Furylacryloyl-phenylalanyl-glycyl-glycine as a synthetic substrate. Consequently, the $\mathrm{Cobas}^{\circledR} 8000$ (Cobas ${ }^{\circledR}$ 8000, Roche Diagnostics GmbH, Mannheim, Germany) was performed using the ACE kinetic test (BÜHLMANN Laboratories $A G$, Schönenbuch, Switzerland).

Statistical evaluation was carried out using the program SPSS ${ }^{\circledR}$ statistics version 21. Normal distribution was carried out by exploratory data analysis with display of normal distribution diagrams ( $Q Q$ diagram) and the Kolmogorov-Smirnov and
Shapiro-Wilk test methods. The Shapiro-Wilk test did not reject the null hypothesis in significance at a value of $p<0.05$. The coefficient of variation was calculated for each patient from the two laboratory measurements and an average value for all patients was formed.

Measurements of the plasma ACE concentration showed no deviation from the normal distribution at any examination points. Therefore, the statistical evaluation in Group 1 was carried out using the paired T-Test and in Group 2 using analysis of variance.

\section{Results}

\section{Clinical examination}

The general health condition of all 25 horses in this study was undisturbed at every stage of the investigation. Fourteen of the 25 patients were diagnosed with a systolic heart murmur $(56 \%)$ and eleven had a diastolic heart murmur (44\%). The remaining clinical examination was inconspicuous in all patients and at all examination points. Quality and quantity of heart murmurs did not change throughout the study.

The acceptance of oral medication was good for all horses, which is based on owner's statements. None of the horses tested showed any adverse effects.

Blood electrolytes and clinical chemistry were without any findings at all examination points.

Measuring plasma ACE concentration was possible in any cases. No significant correlation of plasma ACE activity with either age, weight or size could be found $(p=0.01)$.

Group 1 showed a median ACE plasma concentration of $67.36 \pm 12.37 \mathrm{U} / \mathrm{L}$ prior and 84.4 $\pm 12.27 \mathrm{U} / \mathrm{L}$ post therapy. The ACE increase was statistically significant and is shown in Figure 1. The difference between the mean values was $\Delta=17.04 \mathrm{U} / \mathrm{L}(\mathrm{n}=11, \mathrm{p}=0.00)$.

The three-month therapy with enalapril also had a statistically significant impact on the ACE plasma concentration in Group 2. However, the three-month phase without drug administration showed no effect on the ACE plasma concentration. An ACE plasma concentration of $69.43 \pm 16.34 \mathrm{U} / \mathrm{L}$ was measured at the first investigation, $69.78 \pm 14.62 \mathrm{U} / \mathrm{L}$ at the second examination and a concentration of $83.32 \pm 18.08 \mathrm{U} / \mathrm{L}$ after the three-month therapy. The difference in the mean valuesbetween the second and third examination time was $\Delta=14.54 \mathrm{U} / \mathrm{L}(\mathrm{n}=14, \mathrm{p}=0.00$, Figure 2$)$.

The ACE measurements showed a low coefficient of variation with values between $V=0.016$ and 0.04 .

\section{Discussion}

ACE activity - An increase of ACE activity could be shown in our study post a three-month therapy with enalapril, while there was no significant difference between the examination 
points in horses undergoing no therapy. This is controversial, as we were expecting a lowered ACE plasma concentration with enalapril. Enalapril is reported to inhibit the production of ACEs and, thus, lower the ace plasma concentration (Franco et al. 2011 1). A study performed previously by Sleeper et. al could not determine any change in ACE plasma activity in healthy pony breed stallions either (Sleeper et al. 2008). Studies on enalapril in human medicine show contradictory results. According to older studies, plasma ACE concentrations in long-term therapy tend to rise again after a measurable shortage in ACE concentration. However, only the initial values were achieved and no significantly higher values were shown (Johnston et al. 1986, Liao et al. 1995). Our study showed a significantly higher ACE concentration post treatment when compared to initial values prior to dosage. An increase in ACE plasma concentration was shown in a recent study performed in humans, however, despite inhibition of the RAAS in long-term application of enalaprilat. This increase in ACE plasma activity corresponds to the results shown in our study. A possible cause for this result could be the lack of a negative feedback mechanism. The ACE is bound to enalapril and, thus, does not interact with aldosterone 2, which increases ACE production (Schilders et al. 2014).

The physical condition and training of the horses can have an impact on the ACE concentration (Richard et al. 2010, de Mello Costa et al. 2011 ). The physical condition and training of the horses in our study did not change during the trials. Previous studies report lower ACE concentrations in horses that were only poorly trained (Richard et al. 2010, de Mello Costa et al. 2011 b). The season has been reported as a major cause of changes in ACE production (Coomer et al. 2003, de Mello Costa 2010). The effect of the season on the ACE concentration was not considered in our study.

Oral bioavailability - The oral bioavailability of enalapril seems to be low in healthy horses (Gardner et al. 2004, Gomez-Diez et al. 2014). Gardner et al. (2004) could not measure enalapril or enalaprilat in blood samples in their study after oral application. However, there was a tendency to ACE inhibition and a blood pressure lowering effect was observed.

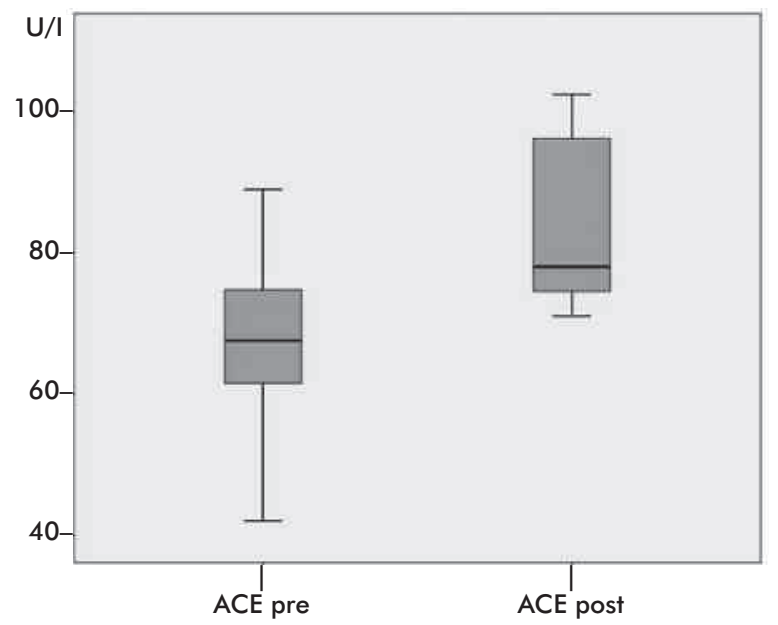

Fig. 1 Concentration of plasma concentration of the angiotensin-converting enzyme (ACE) directly prior (pre) and post three-month therapy in Group 1.
The metabolism of the prodrug enalaprilat is good and so is the bond to the ACE (Muir et al. 2001, Gardner et al. 2004). A possible cause of varying oral bioavailability of ACE inhibitors could depend on various transport mechanisms through the intestine. In addition to passive diffusion, a peptide-based transport is carried out in the small intestine. Enalapril has been shown to have a low affinity to PEPT-2, therefore, its uptake is down mainly through PEPT-1 or other transport mechanisms (Rubio-Aliaga and Daniel 2002). However, the presence of these transport mechanisms in horses is still largely unknown. Two peptide-conveyed transport mechanisms were detected in the equine jejunum. However, it has not yet been clarified whether inclusion of enalapril is performed through one of these transport mechanisms (Cehak et al. 2013).

Poor oral bioavailability of enalapril led to new studies of various alternative ACE inhibitors in the horse. The best efficacy, based on a lowering of the ACE plasma activity, has been proven for ramipril and benazepril in the horse (Afonso et al. 2013, Munoz et al. 2016). A slight increase in inhibition of the ACE activity can be shown by a dosage increase of $0.5 \mathrm{mg} / \mathrm{kg}$ to $2 \mathrm{mg} / \mathrm{kg}$. Nevertheless, the highest dosage only led to a maximum ACE inhibition of 30\% (Gomez-Diez et al. 2014). In addition, Schilders et al. (2014) could not determine any improvements in human medicine based on a dosage increase.

Methods of the analysis - The extraction of blood samples and measurement method of the ACE plasma activity using FAPPG as a substrate was used in previous studies in the horse and, therefore, also chosen for our study (de Mello Costa et al. 2011 a, Afonso et al. 2013). Creating reference values for ACE plasma activity is difficult due to different ACE genotypes. The reference values in humans are determined to vary between 13.3 and $63.9 \mathrm{U} / \mathrm{L}$ (Camos et al. 2012). Studies in healthy horses which, as in our study, used FAPPG as substrate for analysis showed slightly higher values (Costa et al. 2011, Afonso et al. 2013, Munoz et al. 2016) Our results agree with those of Costa et al. (2016) $(86 \pm 18 \mathrm{U} / \mathrm{L})$ and Afonso et al. (2013) $(59 \pm 13.4 \mathrm{U} / \mathrm{L})$. In contrast to that, Munoz et al. (2016) showed slightly higher

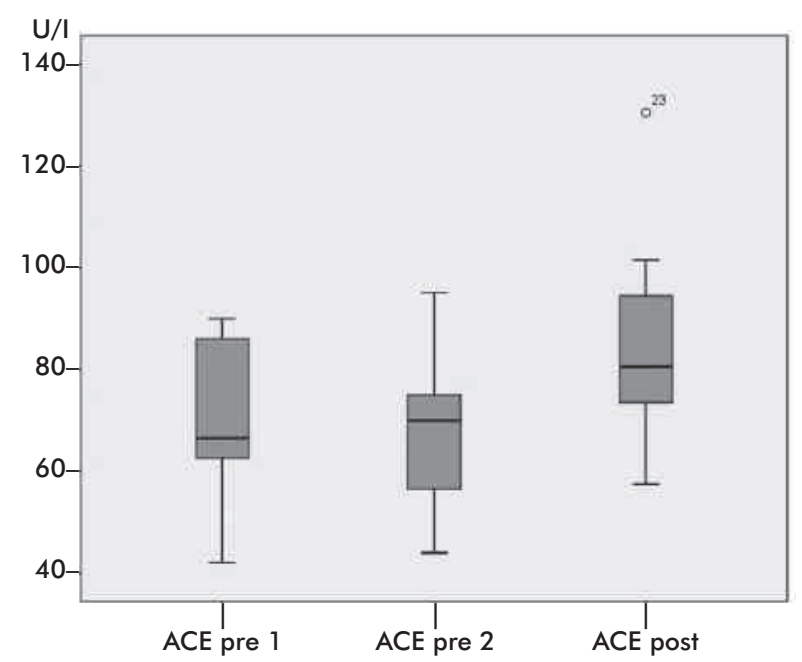

Fig. 2 Plasma concentration of the ACE of the patients in Group 2 at the three pre-therapy examination points (pre 1), directly prior (pre 2) and directly post the therapy (post). 
values (80-120 U/L) (Costa et al. 2011, Camos et al. 2012, Munoz et al. 2016).

An impact of daytime and stress on ACE activity was presumably low in our study, as almost all samples were taken in a stress-free environment and atmosphere at around 7.45 a.m.

One major criticism of our study is that we did not consider the period between the last administration of enalapril and the sampling of blood samples, allowing a varying time interval between 2 and 22 hours. The maximum effects of ACE inhibitors were shown between two and four hours after oral application in dogs and humans (Swanson et al. 1984, Juillerat et al. 1990, Ware 2006, Richter et al. 2014). A study in horses showed a detectable effect of ramipril 24 hours after administration, while oral administration of enalapril only led to a lowered tendency of ACE activity between 45 and 120 minutes post application (Afonso et al. 2013).

Our present work did not measure blood pressure. No change in blood pressure after intravenous and oral administration of enalapril at different doses could be found in a study in healthy horses (Gomez-Diez et al. 2014). According to literature, feeding seems to have no influence on the maximum effect of ACE inhibitors (Afonso et al. 2013). Therefore, the horses in our study had access to water and hay ad libitum.

Our results were based on ACE plasma activity. However, part of the ACE is bound in tissues and the blood vessel endothelial. The latter especially seems to have great hemodynamic meaning (MacFayden et al. 1990). The ACE plasma concentration represents the dissolved form, created by separating membrane-bound enzymes (Xiao et al. 2004, Fleming 2006). The ability to bind to tissue-bounded ACE depends on the lipophilicity and penetration ability of the ACE inhibitor. However, no difference in treatment success with ACE inhibitors with different lipophilicity could be found in clinical trials (Kohkayasit et al. 2014). A maximum ACE inhibition of 55 has been measured for the ACE inhibitors ramipril and benazepril at $80 \%$ in healthy horses. On the other hand, only an ACE inhibition of about $40 \%$ was detected for enalapril and quinalapril (Munoz et al. 2016, Serano-Rodriguez et al. 2016).

The ACE inhibitors have a positive influence on neuroendocrine activity, especially the RAAS (Swedberg et al. 1990). The ACE hydrolyzes endogenous peptides, such as Angiotensin II, Kallidin, Bradykinin, substance P, Angiotensin 1-7, N-Acetyl-Seryl-Aspartyl-Lysyl-proline and amyloid-beta-protein (Welches et al. 1993, Skidgel and Erdös 2004, Greven et al. 2007, Devin et al. 2014). We did not analyze the influence of enalapril on these peptides in our work, but further evaluation of the peptides could be useful for future studies.

\section{Missing placebo group}

There was no placebo group, which is one major criticism of our study. Heart disease can take an individual course, that is why it is difficult to find comparable subjects for a placebo group especially with a low number of patients. Therefore, a three-month period without medication was chosen in Group 2 to obtain a tendency of the individual course of the disease in each animal. Owners and investigators knew that the horse did not receive any treatment during this period. However, this is not suitable for a placebo group.

\section{Conclusion}

Enalapril $\left(E\right.$ alatab $\left.{ }^{\circledR}\right)$ showed good tolerance with no observed side effects. Contrary to expectations, we could show a statistically significant increase in the serum ACE concentration post administration of enalapril per os. One possible cause could be the lack of a negative feedback mechanism. The ACE is bound to enalapril and, thus, does not interact with aldosterone II, which increases ACE production.

\section{References}

Afonso T., Giguere S., Rapoport G., Berghaus L. J., Barton M. H., Coleman A. E. (2013) Pharmacodynamic evaluation of 4 angiotensin-converting enzyme I inhibitors in healthy adult horses. J. Vet. Intern. Med. 27, 1185-1192; DOI 10.1111/jvim.12153

Bonagura J. D., Reef V. B., Schwarzwald C. C. (2010) Chapter 8 Disorders of the Cardiovascular System. In: Reed S. M., Bayly W. M., Sellon D. C., eds. Equine Internal Medicine (Third Edition). Saint Louis, MO: W. B. Saunders. 372-487

Camos S., Cruz M. J., Morell F., Sole E. (2012) Genetic-based reference values for angiotensin-converting enzyme (ACE) according to I/D polymorphism in a Spanish population sample. Clin. Chem. Lab. Med. 50, 1749-1753; DOI 10.1515/cclm2012-0042

Cehak A., Schroeder B., Feige K., Breves G. (2013) In vitro studies on intestinal peptide transport in horses. J. Anim. Sci. 91, 52205228; DOI 10.1016/i.cbpa.2011.11.005

Coomer R. P. C., Forhead A. J., Bathe A. P., Head M. J. (2003) Plasma angiotensin-converting enzyme (ACE) concentration in Thoroughbred racehorses. Equine Vet. J. 35, 96-98; DOI 10.2746/ 042516403775467487

Costa M. F. M., Davies H. M., Anderson G. A., Slocombe R. F. (2011) Effects of two training protocols on Angiotensin I-converting enzyme (ACE) activity in horses. Equine Vet. J. 43, 466-470; DOI 10.1111/i.2042-3306.2010.00320.x

Devin J. K., Pretorius M., Nian H., Yu C., Billings F. T., Brown N. J. (2014) Substance $P$ increases sympathetic activity during combined angiotensin-converting enzyme and dipeptidyl peptidase-4 inhibition. Hypertension. 63, 951-957; DOI 10.1161/HYPERTENSIONAHA. 113.02767

Endringer D. C., Oliveira O. V., Braga F. C. (2014) In vitro and in silico inhibition of angiotensin-converting enzyme by carbohydrates and cyclitols. Chem. Pap. 68, 37-45; DOI 10.2478/s11696013-0407-8

Fagyas M, Úri K, Siket IM, Daragó A, Boczán J, Bányai E, Édes I, Papp $Z$, Tóth A. (2014) New perspectives in the renin-angiotensin-aldosterone system (RAAS) I: endogenous angiotensin converting enzyme (ACE) inhibition. Plos. One. 9, 11; DOI 10.1371/journal. pone.0093719

Fleming I. (2006) Signaling bythe angiotensin-converting enzyme. Circ. Res. 9, 887-896; DOI 10.1161/01.RES.0000217340.40936.53

Franco R. P., Pereira G. T., Camacho A. A. (2011) Clinical evaluation of enalapril maleate and furosemide usage in dogs with degenerative myxomatous mitral valve, chf functional class lb. Pesq. Vet. Bras. 31, 791-797; DOI 10.1590/S0100-736X2011000900011 
Gardner S. Y., Atkins C. E., Sams R. A., Schwabenton A. B., Papich M. G. (2004) Characterization of the pharmacokinetic and pharmacodynamic properties of the angiotensin-converting enzyme inhibitor, enalapril, in horses. J. Vet. Intern. Med. 18, 231-237; DOI $10.1892 / 0891-6640(200418<231$ : cotpap $>2.0 . c 0 ; 2$

Gehlen H., Ammer H. (2010) Pharmakotherapie. In: Gehlen H., ed. Pferdekardiologie. Hannover: Schlüttersche. 155-164

Gehlen H., Vieht J. C., Stadler P. (2003) Effects of the ACE inhibitor Quinapril on echocardiographic variables in horses with mitral valve insufficiency. J. Vet. Med. A. 50, 460-465; DOI 10.1046/j.1439-0442.2003.00580.x

Goltz A., Gehlen H., Rohn K., Stadler P. (2009) Therapy of atrial fibrillation with class-1A and class-1C antiarrhythmic agents and ACE inhibitors. Pferdeheilkunde. 25, 220-227; DOI 10.21836/ PEM20090304

Gomez-Diez M., Munoz A., Caballero J. M. S., Riber C., Castejon F., Serrano-Rodriguez J. M. (2014) Pharmacokinetics and pharmacodynamics of enalapril and its active metabolite, enalaprilat, at four different doses in healthy horses. Res. Vet. Sci. 97, 105-110; DOI 10.1016/i.rvsc.2014.06.006

Greven J., von Knobloch R., Lübbecke F. (2017) Pharmaka mit Einfluss auf die Nieren, den Wasser-, Elektrolyt- und Säure-Basen-Haushalt. In: Estler C.-J., Schmidt H., von Hirschhausen E., eds. Pharmakologie und Toxikologie für Studium und Praxis. Stuttgart: Schattaver. 549-596

Guglielmini C., Giuliani A., Testoni S., Corletto F., Bernardini D. (2002) Use of an ACE inhibitor (ramipril) in a horse with congestive heart failure. Equine Vet. Educ. 14, 297-302; DOI 10.1111/ j.2042-3292.2002.tb00193.x

Johnston C. I., Jackson B., Cubela R., Larmour I., Arnolda L. (1986) Evaluation of angiotensin converting enzyme (ACE) in the pharmacokinetics and pharmacodynamics of ACE inhibitors. J. Cardiovasc. Pharmacol. 8, 9-14; DOI 10.1097/00005344$198600081-00003$

Johnston C. I., Risvanis J. (1997) Preclinical pharmacology of angiotensin II receptor antagonists: update and outstanding issues. Am. J. Hypertens. 10, 306-310; DOI 10.1016/s0895-7061 (97)00388-9

Juillerat L., Nussberger J., Menard J., Mooser V., Christen Y., Waeber B., Graf P, Brunner H. R. (1990) Determinants of angiotensin-II generation during converting enzyme-inhibition. Hypertension. 16, 564-572; DOI 10.1161/01.hyp.16.5.564

Kasi V. S, Xiao H. D., Shang L. L., Iravanian S., Langberg J., Witham E. A., Jiao Z., Gallego C. J., Bernstein K. E., Dudley S. C. Jr. (2007) Cardiac-restricted angiotensin-converting enzyme overexpression causes conduction defects and connexin dysregulation. Am. J. Physiol.-Heart C. 293, 182-192; DOI 10.1152/ ajpheart.00684.2006

Kohkayasit P., Surachetpong S. (2013) Short term echocardiographic and clinical effects of ramipril on dogs with asymptomatic degenerative mitral valve disease. Thai. J. Vet. Med. 43, 337-346

Liao Y. B., Husain A. (1995) The chymase-aniotensin system in humans - biochemistry, molecular-biology and the potential role in cardiovascular-diseases. Can. J. Cardiol. 11, 13-19

MacFadyen R. J., Lees K. R., Reid J. L. (1991) Tissue and plasma angiotensin converting enzyme and the response to ACE inhibitor drugs. Br. J. Clin. Pharmacol. 31, 1-13; DOI 10.1111/j.13652125.1991.tb03851.x

de Mello Costa M. F. (2010) Angiotensin-converting enzyme (ACE) in horses and its relationship to performance and fitness. The University of Melbourne

de Mello Costa M. F., Anderson G. A., Davies H. M., Slocombe R. $F$. (2011) Effects of acute exercise on angiotensin I-converting enzyme (ACE) activity in horses. Equine Vet. J. 44, 487-489; DOI 10.1 111 1/i.2042-3306.2011.00461.x

de Mello Costa M. F., Carmona A. K., Alves M. F. M., Ryan T. M., Davies H. M., Anderson G. A. (201 1 a) Determination of angiotensin I-converting enzyme activity in equine blood: lack of agreement between methods of analysis. J. Vet. Sci. 12, 21-25; DOI 10.4142/jvs.2011.12.1.21 de Mello Costa M. F., Davies H. M., Anderson G. A., Slocombe R. F. (201 1 b) Effects of two training protocols on Angiotensin I-converting enzyme (ACE) activity in horses. Equine Vet. J. 43, 466-470; DOI 10.1111/j.2042-3306.2010.00171.x

Muir W. W., Sams R. A., Hubbell J. A. E, Hinchcliff K. W., Gadawski J. (2001) Effects of enalaprilat on cardiorespiratory, hemodynamic, and hematologic variables in exercising horses. Am. J. Vet. Res. 627, 1008-1013; DOI 10.2460/ajvr.2001.62.1008

Munoz A., Esgueva M., Gomez-Diez M., Serrano-Caballero J. M., Castejon-Riber C., Serrano-Rodriguez J. M. (2016) Modulation of acute transient exercise-induced hypertension after oral administration of four angiotensin-converting enzyme inhibitors in normotensive horses. Vet. 208, 33-37; DOI 10.1016/j.tvjl.2015.10.036

Packer M. (1992) The neurohormanal hypothesis - a theory to explain the mechanism of disease progression in heart failure. J. Am. Coll. Cardiol. 20, 248-254; DOI 10.1016/0735-1097(92)90167-I

Richard E. A., Fortier G. D., Pitel P. H., Dupuis M. C., Valette J. P., Art T., Denoix J. M., Lekeux P. M., Erck E. V. (2010) Sub-clinical diseases affecting performance in Standardbred trotters: Diagnostic methods and predictive parameters. Vet. J. 184, 282-289; DOI 10.1016/i.tvil.2009.04.016

Richter A., Löscher W., Ungemach F. R. (2014) Herz- und kreislaufwirksame Pharmaka. In: Löscher W, Richter A., Potschka H., eds. Pharmakotherapie bei Haus- und Nutztieren. Berlin, Wien: Parey. 173-198

Rubio-Aliaga I., Daniel H. (2002) Mammalian peptide transporters as targets for drug delivery. Trends in Pharmacological Sciences. 23, 434-440; DOI 10.1016/s0165-6147(02)02072-2

Sage A., Mogg T. D. (2010) Chapter 7 - Pharmacology of drugs used to treat cardiac disease. In: Marr C. M., Bowen I. M., eds. Cardiology of the Horse, Second Edition. Edinburgh: Saunders Elvesier. 75-87

Schilders J. E. M., Wu H. Y., Boomsma F., van den Meiracker A. H., Danser A. H. J. (2014) Renin-angiotensin system phenotyping as a guidance toward personalized medicine for ACE inhibitors: can the response to ACE inhibition be predicted on the basis of plasma renin or ACE? Cardiovasc. Drugs Ther. 28, 335-345; DOI 10.1007/s10557-014-6537-6

Serrano-Rodríguez J. M., Gómez-Díez M., Esgueva M., CastejónRiber C., Mena-Bravo A., Priego-Capote F., Serrano Caballero J. M., Muñoz A. (2016) Pharmacokinetics and pharmacodynamics of ramipril and ramiprilat after intravenous and oral doses of ramipril in healthy horses. Vet. J. 208, 38-43

Skidgel R. A., Erdös E. G. (2004) Angiotensin converting enzyme (ACE) and neprilysin hydrolyze neuropeptides: a brief history, the beginning and follow-ups to early studies. Peptides. 25, 521-525

Sleeper M. M., McDonnell S. M., Ely J. J., Reef V. B. (2008) Chronic oral therapy with enalapril in normal ponies. J. Vet. Cardiol. 10, 111-115; DOI 10.1016/i.jvc.2008.08.002

Swanson B. N., Vlasses P. H., Ferguson R. K., Bergquist P. A., Till A. E., Irvin J. D., Harris K.(1984) Influence of food on the bioavailability of enalapril. J. Pharm. Sci. 73, 1655-1657; DOI 10.1002/ ips.2600731146

Swedberg K., Eneroth P., Kjekshus J., Snapinn S. (1990) Effects of enalapril and neuroendocrine activation on prognosis in severe congestive heart failure (follow-up of the CONSENSUS trial). Am. J. Cardiol. 66, 40-45; DOI 10.1016/0002-9149(90)90475-g

Unger T. (2002) The role of the renin-angiotensin system in the development of cardiovascular disease. Am. J. Cardiol. 89, 3-9; DOI 10.1016/s0002-9149(01)02321-9

Ware W. A. (2006) Kapitel 1 - Kardiovaskuläre Erkrankungen. In: Fischer U, ed. Innere Medizin der Kleintiere. München: Nelson, Richard W., Couto, C. Guillermo. 1-219

Welches W. R., Brosnihan B. K., Ferrario C. M. (1993) A comparison of the properties and enzymatic activities of three angiotensin processing enzymes: angiotensin converting enzyme, prolyl endopeptidase and neutral endopeptidase 24.1 1. Life Sci. 52, 1461-1480

Xiao H. D., Fuchs S., Frenzel K., Teng L., Bernstein K. E. (2004) Circulating versus local angiotensin II in blood pressure control: Lessons from tissue-specific expression of angiotensin-converting enzyme (ACE). Crit. Rev. Eukaryot. Gene. Expr. 14, 137-145 


\section{Auswirkung des ACE-Hemmers Enalapril auf die ACE-Plasmakonzentration bei Pferden mit linksseitigen Herzklappeninsuffizienz}

Die Aktivierung des Renin-Angiotensin-Aldosteron-Systems spielt eine entscheidende Rolle im Verlauf einer Herzerkrankung. ACE-Hemmer bieten einen möglichen therapeutischen Ansatzpunkt dieser Aktivierung entgegenzuwirken. Die beiden Hauptwirkungen bestehen in der Hemmung der Produktion von Angiotensin-2 und der Hemmung des Abbaus von Bradykinin. Die verringerte Angiotensin-2-Konzentration bewirkt eine venöse und arterielle Vasodilatation und eine Verringerung des Plasmavolumens, wodurch es zu einer Vor- und Nachlastsenkung ohne Anstieg der Herzfrequenz kommt. Die Folge ist eine erhöhte Auswurffraktion und ein verringertes enddiastolisches Volumen. In der Humanmedizin ist der Einsatz von ACE-Hemmern weit verbreitet und mit diversen, groß angelegten Studien untersucht. ACE-Hemmer gelten beim Pferd mit Mitral- und Aortenklappeninsuffizienz als kardioprotektiv und werden therapeutisch bei Herzversagen eingesetzt. Es gibt nur wenige Studien über die Anwendung bei herzkranken Pferden und ihre genaue Dosierung sowie ihr genauer Effekt sind noch weitestgehend unbekannt. Enalapril zählt zu den empfohlenen ACE-Hemmern, obwohl von einer schlechten oralen Bioverfügbarkeit bei gesunden Pferden berichtet wird. Ziel dieser Arbeit war es, den Effekt des ACE-Hemmers Enalapril bei oraler Applikation in einer Dosierung von 0,5 mg/kg Körpergewicht über einen Behandlungszeitraum von drei Monaten auf die ACE-Plasma Konzentration zu untersuchen.

In diese Studie wurden 27 Pferde bei denen im Vorfeld echokardiographisch eine Mitralklappen- oder Aortenklappeninsuffizienz diagnostiziert wurde integriert. Die 27 Pferde wurden in 2 Gruppen eingeteilt. Die Pferde in Gruppe 1 ( $n=12)$ wurden zweimal im Abstand von drei Monaten untersucht. Vor der ersten Untersuchung erhielt keines der Tiere Medikamente. Zwischen der ersten und der zweiten Untersuchung erhielten die Probanden einmal täglich Enalaprilmaleat (Enalatab ${ }^{\circledR} 20 \mathrm{mg}, \mathrm{CP}$-Pharma Handelsgesellschaft mbH, Burgdorf, Deutschland) per os in der Dosierung 0,5 mg/kg Körpergewicht. Sieben dieser Patienten hatten eine Aortenklappeninsuffizienz und fünf eine Mitralklappeninsuffizienz. Die Patienten in Gruppe 2 ( $n=15)$ wurden dreimal untersucht. In den ersten drei Monaten erhielten die Pferde keine Medikamente. In den darauffolgenden drei Monaten wurde den Tieren einmal täglich Enalaprilmaleat in derselben Dosierung wie bei den Pferden in Gruppe 1 verabreicht. In dieser Gruppe wiesen sieben Probanden eine Aortenklappeninsuffizienz und 8 eine Mitralklappeninsuffizienz auf.

Die Bestimmung der ACE-Plasmaktivität wurde bei der Firma Laboklin GmbH\&Co.KG photometrisch durchgeführt. Die Messung der ACE-Plasmakonzentration war in allen Fällen möglich. Es konnte keine Korrelation der Plasma-ACE-Aktivität mit Alter, Gewicht oder Größe gefunden werden. In Gruppe 1 betrug die mittlere ACE-Plasmakonzentration vor der Therapie 67,36 $\pm 12,37 \mathrm{U} / \mathrm{I}$ und nach der Therapie $84,4 \pm 12,27 \mathrm{U} / \mathrm{I}$. Der Anstieg war statistisch signifikant. Die Differenz der Mittelwerte betrug $\Delta=17,04 \mathrm{U} / \mathrm{I}$ ( $\mathrm{n}=11, \mathrm{p}=0,0)$. In Gruppe 2 hatte die dreimonatige Therapie ebenfalls eine statistisch hochsignifikante Auswirkung auf die ACE-Plasma-Konzentration. Die dreimonatige Phase ohne Medikamentengabe zeigte dagegen keinen Effekt auf die ACE-Plasmakonzentration. Es wurde zum ersten Untersuchungszeitpunkt eine ACE-Plasmakonzentration von 69,43 $\pm 16,34 \mathrm{U} / \mathrm{l}$, zum zweiten Untersuchungszeitpunkt von 69,78 $\pm 14,62 \mathrm{U} / \mathrm{l}$ und im Anschluss an die dreimonatige Therapie eine Konzentration von 83,32 $\pm 18,08 \mathrm{U} /$ I gemessen. Die Differenz der Mittelwerte betrug zwischen dem zweiten und dritten Untersuchungszeitpunkt $\Delta=14,54 \mathrm{U} / \mathrm{I}(\mathrm{n}=14, \mathrm{p}=0,0)$. Die ACE-Messungen zeigten einen niedrigen Variationskoeffizienten mit Werten zwischen $\mathrm{V}=0,016$ und $\mathrm{V}=0,04$.

Enalapril (Enalatab ${ }^{\circledR}$ ) zeigte eine gute Verträglichkeit bei den Tieren in der vorgestellten Studie. Diese Studie zeigte zwar einen Effekt des ACE-Hemmers Enalapril bei Pferden mit einer linksseitigen Herzklappeninsuffizienz auf das Renin-Angiotensin-Aldosteron-System. Die Resultate widersprachen jedoch den Erwartungen, dass Enalapril die ACE-Konzentration senkt. Eine mögliche Ursache dafür könnte in dem fehlenden negativen Feedback-Mechanismus liegen. Das ACE ist an Enalapril gebunden und interagiert somit nicht mit Aldosteron 2, wodurch die ACE-Produktion steigt. Es wären weitere Studien zur kardialen Wirksamkeit wünschenswert.

Schlüsselwörter: ACE Hemmer, Serum ACE Aktivität, Pferd, Herzinsuffizienz 